\title{
IFRS 9 TRANSITION EFFECT ON FINANCIAL STABILITY OF KOSOVO COMMERCIAL BANKS
}

\author{
Besmir ÇOLLAKU, PhD. C.(1) 1* \\ Skender AHMETI, PhD. (iD) 2 \\ Muhamet ALIU, PhD. (Di) 3



\section{Article history:}

Submission 19 November 2020

Revision 10 December 2020

Accepted 25 January 2021

Available online 30 April 2021

\section{Keywords: \\ IFRS 9 , \\ Expected Credit Loss, \\ Impairments, \\ Re-measurement \\ Capital Regulatory, \\ Commercial Banks.}

DOI:

https://doi.org/10.32936/pssj.v5i1.191

\begin{abstract}
A b s t r a c t
From January 1, 2018, most of the commercial banks in Kosovo adopted IFRS 9. The new standard introduces the expected credit loss model to allow for timely recognition of credit losses, estimated not only on the actual credit loss but also on forward-looking information regarding the current loan portfolio. Although, transition phases may lead to increasing impairments and a decrease in banks' equity, which directly influences the financial stability of banks. This paper examines the day-one transition effect of IFRS 9 on the level of assets balance, allowance for loan losses, and capital regulatory class II of banks in Kosovo. To test our hypothesis, we have performed a comparative analysis for the six biggest commercial banks in Kosovo to identify correlation and causality between studied variables. As a statistical technique, we have employed a "paired sample t-test" where we compare financial indicators before and after adopting IFRS 9 to examine the impact on financial stability for commercial banks in Kosovo.

Our results are in line with the results of recent studies in the IFRS 9 field and conclude that the transition phase has a significant influence on the recognition of additional loan impairment but assets and capital regulations are not affected significantly. Results demonstrate the transition to IFRS 9 causes instability and re-consolidation of capital, but in the long-run reduce the possibility for large and sudden losses. Commercial banks in Kosovo should follow a balanced growth approach without compromising the quality of the loan portfolio.
\end{abstract}

\section{Introduction}

The global financial crises exposed the inadequacy of currents standards to present the fair value of financial instruments. The International Accounting Standard (IAS) 39, which has been in use since 2001, has proven to be more critical in the direction of preventing banks from dealing with or/and addressing enormous loan losses, especially during the period of business cycles, that can significantly affect their viability (Ntaikou, D. \& Vousinas, G., 2018). The incurred loss model of IAS 39 allows recognition of loan losses only when financial instruments record losses or when losses will likely to occur. Therefore, the previous models' loan loss provisions in professional jargon are known as "too little, too late" (Frykstrom, N. \& Li, J., 2013; Groff, Z.M. \& Morec, B., 2020; Low, E., Schmidt, E.L \& Thiel, F. L, 2019).

Under these circumstances, the traditional approach to measure impairment allowances or incurred loan losses gradually replaced by the expected credit loss (ECL) model. In 2014, the International Accounting Standard Board (IASB) issued the new standard International Financial Reporting Standard (IFRS 9) Financial Instrument, which became effective in most of the EU countries since January 1, 2018. IFRS 9 introduced the new accounting rules, more principle-based classification and measurement of financial instruments, the forward-looking expected loss impairment model of financial assets, and new 
hedge accounting rules to better align with risk management activities (Groff, Z.M. \& Morec, B., 2020; EY, 2017; IFRS, 2018).

The new requirements derived from the adoption of the standard initially welcomed, but doubts raised regarding its impact on financial stability. Classification and re-measure of assets under IFRS 9 may lead entities to adjust the balance of the assets and changing business cash flow, which affects profit and financial stability. The impairment phase is at the forefront of the standard due to the transition from the incurred losses model to expected credit losses. Regarding this, adopting the ECL will have a significant impact on the banks' business since the loan portfolio presents the main assets in their financial statements (Sultanoglu, 2018). The provisions for loan losses are recognized before they happen, and updated at each reporting to reflect the changes in credit risks since the last reporting period. The credit loss calculated as the present value of cash shortfalls were corresponded to the differences between the cash flows that are due to the contract and the cash flows expected to receive a discount at the original effective interest rate (Laurea, 2018; Frykstrom, \& $\mathrm{Li}$, 2013). In the transition phase, financial stability is directly affected by a decrease in assets balance, changes in cash flow characteristics, and potentially increased impairment allowance, which affects profit and banks' equity. In the early phase, banks may invest additional capital in response to additional loan provisioning and maintain financial stability. Banks that are less capitalized and loan portfolio has problems with quality will be faced with financial problems or will provoke they fail.

In addition to direct impact, banks' financial stability will be affected indirectly through expenses that appear from standard adoption. The implementation of IFRS 9 requests increasing the capacity of banks' departments, training staff, and other costs related to adoption, which influences profit and bank performance (Gulyas, E. \& Somogyi, C., 2019; Deloitte, Fourth Global IFRS Banking Survey - Ready to land, 2014).

The implementation in a sound way by banks, IFRS 9 can contribute to improving banks' credit risk management, increasing transparency, and shunning pro-cyclicality through a timelier recognition of credit losses (Gornjak, 2017; Costa, J.F., Lejard, Ch. \& Paget-Blanc, E., 2018).

This study aims to examine the day-one impact of IFRS 9 implementation and to analyze the qualitative and quantitative effects of this transition on the financial stability of commercial banks in Kosovo. In our study as a sample, we use six commercial banks in Kosovo, which are selected based on bank size through asset value. Data for study needs were obtained from banks' annual reports for the years 2017 and 2018, and financial disclosure was helpful to identify changes and influences of standard adoption. We analyze whether these banks report a significantly different day-one effect of IFRS 9 implementation on the level of assets, level of impairments, and banks' equity as compared to the same indicators under the IAS 39.

In line with expectations, we find that bank assets after remeasuring registered lover balance, banks recognized additional allowances for credit losses under the new impairment model, and in this regard ratio of capital regulation of class II decreases too.

Our study contributes to the topical discussion in the field of financial accounting, focusing on the diverse effects of institutional and regulatory settings on IFRS 9 implementation.

Other parts of this paper put forward a short literature review regarding changes in accounting policy, empirical evidence of IFRS 9 impact on banks financial stability; the third part describes the research methodology used; the fourth part presents the main findings of the study and the last section concludes, with some limitations and future research directions.

\section{Literature Review}

The new regulatory standard for financial instruments introduced a new approach to the calcification and measurement, impairment methodology, fair value, and hedge account (Blažeková, 2018; Groff, Z.M. \& Morec, B., 2020). IFRS 9 replaces the previous IAS 39, and it is effective from January 1, 2018 (EAA, 2019; IASB, 2014). The aim of IFRS 9 is to establish principles on financial reporting for financial instruments, and so one to offer relevant and useful information for related parties. These changes come into effect after years of global review and debate, intending to have a more appropriate level of credit losses recognized earlier in the credit cycle.

As a result, in the transition process to IFRS 9, banks will face a decline in assets, loan loss provisions, and its volatility could increase significantly, as they will respond much more directly to changes in credit risk trends (based on the selected credit model and other characteristics such as economic trends and stress testing analysis) (Charles, T., Shipilovo, A. \& O'Donnell, B., 2017).

\subsection{Transition Changes}

The adoption of IFRS 9 presents a new classification and measurement approach and a new impairment model for financial instruments. The phase of classification and measurement is an area where many changes occur. The classification process of a 
particular financial instrument is determined at initial recognition based on both the business model and cash flow characteristics. Accordingly, financial instruments are either classified/measured at amortized cost (the instrument held to collect contracted cash flow) or at fair value either through comprehensive income (the instruments held to collect or sell, with some exceptions) or through profit or loss (all other instruments) (Groff, Z.M. \& Morec, B., 2020; KPMG, 2016; KPMG, 2016). Banks during classification and measurement should take into consideration also important indicators such as amount, timing, and uncertainty of the banks' future cash flows and all relevant evidence available at the date of the assessment.

Adoption IFRS 9 can influence the measurement base for some financial instruments, mostly notable loans, which are noninstrument hold to collect, and those debt securities, which were initially classified as available for seal as they did not meet the fold-to-maturity classification requirements, but are held under the hold to collect business model under IFRS 9. Changes in measurement bases directly reflect on equity-related categories: a) in case of financial assets originally carried at amortized cost and reclassified on the transition to Fair Value Thorough Profit and lose (FVTPL) or Fair Value through Other Comprehensive Income (FVOCI), the difference in carrying amount at transition date was recognized in bank equity as an adjustment to other comprehensive income or retained earnings as appropriate; b) in the case of financial assets originally classified as available-forsale and reclassified as FVTPL at transition, the related cumulative revaluation reserve was reallocated to retained earnings. Referring to the European Systematic Risk Board (2017), implementing IFRS 9 would not systematically increase the use of fair value in EU banks since they typically grant loans as the most important assets they held to maturity.

The new impairment model based on expected losses will replace the incurred losses model as a response to the concept "too little, too late". IFRS 9 requires the same measurement basis for impairment for all items in the scope of the impairment requirements. The guiding principle of the ECL model is to reflect the general pattern of deterioration or improvement in the credit quality of financial instruments. In the previous impairment model, banks were not allowed to record loss allowance until the real occurrence of an impairment or the existence of a probability of default that is close to or equal to $100 \%$ (Novotny-Farkas, 2016). Thus, IFRS 9 presents significant changes by requiring the record of loan loss provisioning on expected bases, which aim to smooth credit losses by provisioning as soon as the financial assets are recorded on the financial statement (Costa, J.F., Lejard, Ch. \& Paget-Blanc, E., 2018; Fatohu, M., Bock, R. \& Ouenniche, J., 2020). Furthermore, impairment occurs in the three stages. In stage 1 includes all assets fall into the category AC or FVOCI, and banks have to recognize credit loss from the initial recognition of an asset onwards. Whenever banks originate or porches a financial instrument should recognize 12-month ECLs in profit and loss and a loss reserve is created as a proxy for the initial expectation of credit losses. The loss allowance corresponds to an amount equal to cash shortfalls that will result if a default event occurs within 12 months weighted by the probability of this default occurring (Seitz, 2019; Laurea, 2018). Banks will take into account all available information such as banks' actual credit losses experienced, forward-looking information on payment status, and macroeconomic variables (GDP growth rate, unemployment rate, property price, etc. If the credit risk increased significantly and results in that credit quality is not considered to be a low credit risk, full lifetime ECLs are recognized, allocation assets to stage 2 . On stage 3 will be allocated an asset if the level of credit risk increases to the point that it is credit-impaired. The transition from stage to stage is possible depending on the underlying changes in the credit risk assessment. Besides, this paper will not cover the part of hedge accounting because financial institution is not implementing this part yet.

Transition to IFRS 9 requests reclassification and re-measure of financial instruments according to new requirements, determine impairments and provisions in line with ECL model and adjusted earnings and other comprehensive income accordingly. This process of transitions resulted in current assets balance, implication on the allowance for loan loss, which further affected bank equity.

\subsection{The Effect of IFRS 9 on Bank Financial}

\section{Stability: A Review of Empirical Evidence}

IFRS 9 implementation in the early stages was the object of many critics for its organizational, financial, and practical implications on banks' business. The changes that come from new accounting regulations influence profit, impairment, and bank equity itself. Since banks implemented IFRS 9 only recently, the empirical evidence of its true effects is scary.

The majority of studies in the field estimate the day-one effect on financial stability, with emphasis on the ECL model's impact on the capital regulatory. Although IFRS 9 will affect the classification of financial instruments into a fair value, the impact from re-measure will be relevant only for a minority of the banks. Based on the literature, even though a significant re-classification percentagewise amount of assets will remain in its current measurement category (Groff, Z.M. \& Morec, B., 2020; EBI, 2019). 
Refer to EBA (2018), who has undertaken a study with 50 European banks has found that on a simple average about $80 \%$ of total financial assets are measured in AC, Fair Value through Other Comprehensive Income (FVOCI) represents, on simple average, 9\%, of total financial assets. Moreover, Fair Value through Profit and Loss (FVPL) stands at $11 \%$. Based on those statistics, the impact on classification and measurement is quite limited. Reclassification can result in re-measure, e.g. when assets were previously measured at amortized cost and now measured at FVOCI or FVPL. This re-measurement can be both positive and negative. The way that a bank classifies its financial assets could affect how its capital resources and capital requirements are calculated, and create volatility in profit or loss or equity.

Moreover, the adoption of the ECL model will influence to reduce the number of outstanding loans due to impairment that has to be recognized earlier to reflect the real underlying economic value. The results of preliminary studies on the anticipated effect of the IFRS 9 impairment model varied greatly between individual banks, sowing an average anticipated day-one increase in impairments of financial assets between $10 \%$ (EBA, 2018; EY, 2018), and $25 \%$ (Deloitte, SIx Global IFRS Banking Survey. No time like the presnt, 2016), as compared to IAS 39. The European Banking Institutions (2019), in her research with 90 European banks found that some banks on the sample loss slightly more than $1 / 5$ of their equity because, and a few banks experienced positive effects due to favorable macroeconomic development and high percentage of loan portfolio on stage 1.

A Deloitte survey (2016), with 91 banks from Europe, the Middle East \& Africa, Asia Pacific and the Americas indicate that their allowance for credit losses (the balance sheet reserve- which is built up via loan loss charges through the income statement, and draw down by written-off) could increase up to $50 \%$ for some banks. Barclays (2017), indicates that the adoption of IFRS 9 will influence increase provisions for $17 \%$. IFRS 9 recognized more impairments lose burden to the banks compared to IAS 39 and the main driver of it will be the recognition of additional ECLs for the instruments classified in Stage 1 and Stage 2, not that the impairment allowances provided for Stage 3 that are exactly the same with IAS 39.

However, using model estimation on a typical portfolio of corporate loans by EU banks, they showed the IFRS 9 ECL model was more responsive to changes in economic conditions compared to the previous impairment loan losses model. Therefore, many studies conclude that banks will be more capitalized in times of economic expansion and less in contraction periods, compared to the effects of the IAS 39 incurred loss model. The impact of transition on provisioning increase depends also on portfolio quality (Ntaikou, D. \& Vousinas, G., 2018; Sultanoglu, 2018).

As IFRS 9 became effective on January 1, 2018, the first evidence of its actual effect was available following the publications of financial statements for annual report 2018 and 2019. Results of these studies, focusing on the day-one impact on re-measurement, on provisioning and capital regulatory, indicate that the anticipated effects of IFRS 9 as reported in preliminary studies, were estimated. Deloite (2019), analyzed IFRS 9 transition disclosure for main financial indicators in UK banks. All banks' saw increases in total IFRS 9 provisioning of between $16.1 \%$ $58.4 \%$ at transition on 1 January 2018. However, banks claimed that the reported impact was lower than was expected. By the end of the 2018 reporting period, the banks had reflected a decrease in total IFRS 9 impairment provisions of between $(2.3 \%)$ $(34.8 \%)$ due to early write-off policies, strict forward-looking macroeconomic condition incorporated into impairment models, and reclassification to FVPL.

The studies on the field of IFRS 9 transition impacts are in the same lines. The changes that drive from the adoption of new account regulations affect a decrease in assets and increase impairment, which directly influences banks' capital and capital regulations too. The overall equity impact cussed by the adoption of IFRS 9 ranged from minus $26.6 \%$ to plus $4.9 \%$, and the average impact on Capital Equity Tier (CET) 1 ratio was minus 30 bps (EBI, 2019). The impairment caused the largest part of this effect and is mostly negative, but classification and measurement were positive for many banks in the sample. In line with those results, EBA (2018) indicates (45 bps) on the CET 1 ratio and (35 bps) effect on the total capital ratio that derives from the adoption of IFRS 9.

The first available results, therefore, show that the majority of the biggest European banks reported a negative impact on ban equity, which is in line with Basel Committee on Banking Supervisory (2017) and the European Commission (2016) predictions.

\subsection{IFRS 9 Implementation in Kosovo Banks}

The Republic of Kosovo is a unique opportunity to analyze the impact of IFRS 9 on bank equity. According to data from CBK (2020) in Kosovo is operating ten commercial banks, of which foreign-owned are eight and two of them with local ownership. The bank's sector demonstrates stable performance and presents the economic sector with the best organization and performance in the whole country.

Banks are subject to strict supervision from the Central Bank of Kosovo (CBK), and all of them use international financial reporting standards. The decision of CBK ( (2019) that obliges 
commercial banks to implement IFRS 9 from January 1, 2020, it is not something completely new; it is an adjustment and expansion of the capacity to accommodate the requirements deriving from the new standard. Based on annual reports, banks in Kosovo start the implementation of IFRS 9 before the date planned, where nine of ten banks published their annual report for 2018 with IFRS 9.

Table 1. Banks Sector in figures

\begin{tabular}{lrrr} 
Indicators & 2017 & 2018 & 2019 \\
\hline Assets & 3,877 & 4,183 & 4,755 \\
Loans & 2,485 & 2,755 & 3,031 \\
ROA & $2.6 \%$ & $2.5 \%$ & $2.2 \%$ \\
ROE & $21.3 \%$ & $20.2 \%$ & $18.9 \%$ \\
NPL & $3.1 \%$ & $2.7 \%$ & $2.0 \%$ \\
Prov. Cover. & $150.5 \%$ & $152.0 \%$ & $163.5 \%$
\end{tabular}

Source: CBK, Monthly report of Financial System, Dec.2017-Jun 2020

Based on data from Table 1, banks' financial assets have recorded an increase from $€ 3.8$ billion in 2017 to $€ 4.7$ billion in 2019 . This increase in asset value comes mainly from loan portfolio growth on a simple average of $€ 182$ million per year. As is expected, under the IFRS 9 loan, the loan loss is known early and this is reflected in the reduction on ROA and ROE from $2.6 \%$ respectively $21.3 \%$ in 2017 to $2.2 \%$ respectively $18.9 \%$ in 2019 .

Data from tables shows that banks in Kosovo maintain the quality of the loan portfolio. The NPL and Provision Coverage was $3.1 \%$ respectively $150.5 \%$ on 2017 and in 20189 ratios was $2.0 \%$ respectively $163.5 \%$. Based on the literature review previously, the impact of IFRS 9 depends on the quality of the loan portfolio. In this context, referring to current performance indicators it is rational to say that transition to IFRS 9 will have a limited influence on banks' performance in Kosovo.

Ensuring empirical analysis aims to answer the following research questions:

1) How did the implementation of the new standard affect the balance of the assets of Kosovo banks?

2) More specifically, how did the transition from the incurred to the ECL model affect the level of impairment of the financial assets in the Kosovo banks? and

3) How did influence decrease on assets balance and increase on impairment the TIER 2 in the Kosovo banks?

Based on describing the settings, we set the following hypothesis:
$\boldsymbol{H}_{I}$ : There are average differences in assets measured under IAS 39 and assets measured with IFRS 9.

$\boldsymbol{H}_{2}$ : There are average differences between the loan loss allowances of 2017 and those of 2018.

$\boldsymbol{H}_{3}$ : There are average differences between TIER 2 in 2017 and that of 2018 .

\section{Research Methodology}

We measure the day-one impact of IFRS 9 implementation on different indicators for commercial banks in Kosovo. Day one impact is measured by comparing the data from financial statements and notes as of December 31, 2017 (in accordance with IAS 39) and December 31, 2018, available in individual audited annual reports for each bans in the sample. This paper is based on secondary data that individual banks reported through annual reports for indicators such as assets balance, allowance for loan losses, and TIER 2.

The statement of changes in assets for the year 2018 provides information on the opening balance of assets before restatement (December 31, 2017) and opening balance of assets for the reporting periods after restatement (January 1, 2018). The differences between the two figures - the IFRS 9 related effect of changes in accounting policies - represent the total day-one impact on banks assets.

The level of allowances for loan loss is disclosed in the notes to the financial statements. Annual report for the year 2018 includes a comprehensive section on IFRS 9 transaction and disclosure upon the introduction of the new standard. In this section, the cumulative effect of IFRS 9 on each of the two aforementioned equity-related categories is further divided and comprises of effects reclassification and re-measurement, the effect of impairments and provisions.

In 2018, a total of 10 commercial banks were granted authorization to provide banking services. Table 2 presents the list of commercials, information about total assets of individual banks, and their market share.

Table 2. Commercial banks in Kosovo, as of Decembar 31, 2018

\begin{tabular}{lccc}
\hline Banks & $\begin{array}{c}\text { Total assets } \\
\text { Dec, } 12018 \\
\text { (in } € \text { thousand })\end{array}$ & $\begin{array}{c}\text { Market } \\
\text { Share } \\
(\%)\end{array}$ & $\begin{array}{l}\text { Rep. with } \\
\text { SNRF9 }\end{array}$ \\
\hline PCB & 753,983 & 19 & Yes \\
RBKO & 888,913 & 22 & Yes \\
NLB & 668,127 & 17 & Yes \\
TEB & 555,888 & 14 & Yes \\
BKT & 412,307 & 10 & Yes \\
BE & 254,713 & 7 & No \\
BPB & 281,113 & 6 & Yes
\end{tabular}




$\begin{array}{llll}\text { Is Banka } & 114,660 & 3 & \text { Yes } \\ \text { Zirat } & 43,095 & 1 & \text { Yes }\end{array}$

Source: Banks' annual reports. The author calculates market share.

We obtained data for our analysis from audited annual reports of 10 commercial banks. We identified the total effect of the transition to IFRS 9 on banks' total equity and decomposed it to the following components: (1) the impact of reclassification and premeasurement, (2) impairment effect of financial assets, and (3) the impact on TIER 2. For four banks, we identified the total impact on equity but were not able to decompose the cumulative effect into the three aforementioned components due to a lack of disclosures. Therefore, the final sample consists of six commercial banks, representing a vast majority $(88.9 \%)$ of the Kosovo banking sector.

In addition, we would analyze the evolution of the indicators over the transition process using a descriptive statistic, correlation, assessment of middle-range, and construct the statistically parametric test through "paired sample t-test."

\section{Empirical Results and Interpretations}

\subsection{Descriptive Analysis}

In this part of the paper, we will discuss descriptive statistics for all studied variables. The descriptive statistics of the variables used to test our hypothesis (re-measure of assets, allowance for loan loss, and TIER 2) presented in the table below.

Table 3. Effect of day-one transition to IFRS 9 on Equity of Kosovo banks.

\begin{tabular}{lrcc}
\hline Banks & $\begin{array}{c}\text { Effect on assets } \\
\text { re-measure }\end{array}$ & $\begin{array}{c}\text { Effect on loan } \\
\text { loss allowance }\end{array}$ & $\begin{array}{c}\text { Effect on } \\
\text { TIER 2 }\end{array}$ \\
\hline PCB & $-3,061$ & 2,566 & -0.40 \\
RBKO & 3 & 498 & -0.02 \\
NLB & 29 & -372 & 0.13 \\
TEB & $-5,240$ & 3,362 & -1.21 \\
BKT & $-1,675$ & 3,387 & -0.49 \\
BPB & $-1,683$ & 1,190 & -0.92
\end{tabular}

Source: Authors' calculation based on banks' annual reports data.

The data presented in Table 3 shows that the implementation of IFRS 9 has influenced assets to balance corrections, included here loan portfolios. As a result of the classification and re-measure process, the balance of assets on January 1, 2018, compared with assets balance on December 31, 2017, shows decries on assets balance on average varied from $€-5.240$ million $(\mathrm{PCB})$ to $€ 3$ thousand (RBKO). The first three places were held by TEB $(€-$ 5,240 million), PCB (€ -3,061 million) and BPB (€ $-1,683$ million) and in the last places was RBKO with a positive impact $(€+3$ thousand)

As it mentions in the literature review, banks will face a decrease in assets balance as a result of reclassification when assets change measured category from AC to another category of measurements such as FVOCI or FVPL

Referring to data in Table 3 for loan loss allowance for banks in the sample, we can observe that allowance in 2018 are much higher than in 2017. The allowance for loan loss increased on average by $€ 1.7$ million; it varied from $€-489$ thousand (NLB) to $€ 3,387$ million (BKT).

Both decrease in the balance of assets and an increase in the allowance for loan loss will influence capital regulation; in our case the ratio of TIER 2. Most of the banks in the sample recognized decreases on TIER 2 on average $-0.48 \%$; varied from +0.13 (NLB) as the lowest impact to the highest impact $-0.92 \%$ (BPB).

\subsection{Statistical Test of Significance}

To test hypothesis our hypothesis and determine whether the differences between the mean values of the effects of two groups are also statistically significant, we performed the parametric test "paired sample t-test". To evaluate the impact of the transition to IFRS 9, we will compare data for our measurement indicators before and after implementing the new standard.

To test whether the classification under IFRS 9 influences the balance of assets significantly, we collected data about balance assets on December 31, 2017, and on January 1, 2018. We will test on a 5\% level of significance through using a "paired sample t-test".

When X present assets balance before (measured with IAS 39) and $\mathrm{Y}$ present assets balance after (SNRF 9, and as the null hypothesis (H0) considering that classification process will influence decries on assets balance.

In this way, we can write:

$\mathrm{H}_{0}: \mu 1=\mu 2$, which is ecujvalent with test $\mathrm{H}_{0}: \bar{D}=0$

H1: $\mu 1<\mu 2$ (as we expect to conclude that classification will not influence the balance of assets).

Table 4. Testing hypothesis 1

\begin{tabular}{|c|c|c|c|c|}
\hline \multicolumn{5}{|c|}{ Paired Samples Statistics } \\
\hline & Mean & $\mathrm{N}$ & $\begin{array}{c}\text { Std. } \\
\text { Deviation }\end{array}$ & $\begin{array}{l}\text { Std. Error } \\
\text { Mean }\end{array}$ \\
\hline Assets_IAS_39 & 543970 & 6 & 257643 & 105182 \\
\hline Assets_SNRF_9 & 542002 & 6 & 258132 & 105382 \\
\hline
\end{tabular}




\begin{tabular}{l|ccc}
\hline \multicolumn{4}{c}{ Paired Samples Correlations } \\
\hline & $\mathrm{N}$ & Correlation & Sig. \\
Assets_IAS_39 \& & 6 & 1.000 & .000 \\
Assets_SNRF_9 & & & \\
\hline
\end{tabular}

\begin{tabular}{l|lllll}
\hline \multicolumn{7}{c}{ Paired Samples Test } \\
\hline \multirow{2}{*}{ IAS 39 } & Mean & St. dev. & T & df & Sig \\
\cline { 2 - 6 } SNRF_9 & 1967.5 & 2321.5 & 2.076 & 5 & 0.093 \\
\hline
\end{tabular}

Source: Calculation done by author

The result of variables "Assets - IAS 39" and "Assets - IFRS 9" shows that balance of assets according to IAS $39=€ 543,970$ million, and the average of assets according to IFRS $9=€ 542,002$ million, which shows decries on assets balance. The correlation between variables is $R=1.00$, indicated that absolute positive correlation, interpreted as measuring of assets under IFRS 9 has a significant impact on the decline in the total asset balance. The results of the paired sample t-test showed the level of significance is $9.3 \%$ and $\mathrm{T}=2.076$, which indicates approval of the alternative hypothesis (H1), and in this way, we conclude that there is no average difference between assets measured by IAS 39 and IFRS 9 at commercial banks in Kosovo.

To test the second hypothesis, we have gathered data for loan loss allowances for the year 2017 and 2018 for six commercial banks.

Table 5. Testing hypothesis 2

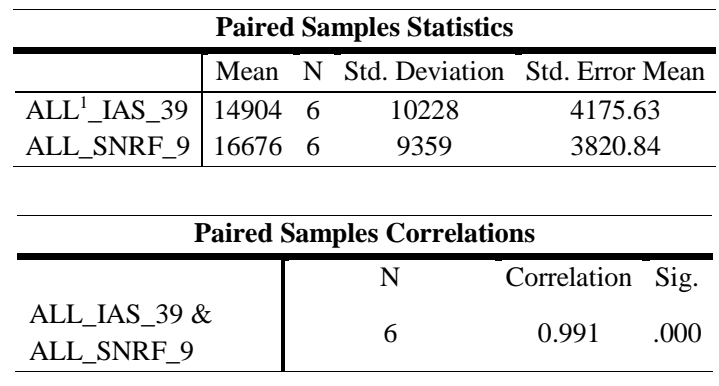

\section{Paired Samples Test}

\begin{tabular}{l|lllll}
\hline & Mean & St. dev. & T & df & Sig \\
\cline { 2 - 6 } ALL_IAS_39 & -1771.8 & 1570 & -2.76 & 5 & 0.04 \\
ALL_SNRF_9 & & & & & \\
\hline
\end{tabular}

Source: Calculation done by author

The result of variables "Lon loss allowance - IAS 39" and "Loan loss allowances - IFRS 9" shows that allowances for loan loss according to IAS $39=€ 14,904$ million and the average of loan loss allowances according to IFRS $9=€ 16,676$ million. Based on these results, the loan loss allowances increased because of the

\footnotetext{
${ }^{1}$ Allowance for Loan Losses - ALL
}

transition to IFRS 9. The correlation between variables is $\mathrm{R}=0.991$, indicated that a strong positive correlation interpreted as the transition to IFRS 9 has a significant impact on increasing allowances for loan losses.

The results of the paired sample t-test showed the level of significance is $4.0 \%$ and $\mathrm{T}=2.76$, which indicate that we approve the null hypothesis $(\mathrm{H} 0)$ and rejecting the alternative (H1). We can conclude that there are significant differences between the averages of allowances for loan losses according to IAS 39 and IFRS 9 at commercial banks in Kosovo.

Table 6 shows there are no significant differences in the TIER 2 ratio for commercial banks in Kosovo. To test the last hypothesis, we gather data for the TIER 2 ratio for the year 2017 and 2018 .

Table 6. Testing hypothesis 3

\begin{tabular}{|c|c|c|c|c|c|c|}
\hline \multicolumn{7}{|c|}{ Paired Samples Statistics } \\
\hline & Mean & $\mathrm{N}$ & \multicolumn{2}{|c|}{ Std. Deviation } & \multicolumn{2}{|c|}{ Std. Error Mean } \\
\hline TIER2_IAS_39 & \multicolumn{2}{|c|}{$17.59 \quad 6$} & \multicolumn{2}{|l|}{2.81} & \multicolumn{2}{|c|}{1.149} \\
\hline TIER2_SNRF_9 & \multicolumn{2}{|c|}{$16.64 \quad 6$} & \multicolumn{2}{|l|}{2.71} & \multicolumn{2}{|c|}{1.108} \\
\hline \multicolumn{7}{|c|}{ Paired Samples Correlations } \\
\hline \multicolumn{2}{|l|}{$\begin{array}{l}\text { TIER2_IAS_39 \& } \\
\text { TIER2_SNRF_9 }\end{array}$} & \multicolumn{2}{|r|}{$\begin{array}{l}\mathrm{N} \\
6\end{array}$} & \multicolumn{3}{|c|}{$\begin{array}{cc}\text { Correlation } & \text { Sig. } \\
0.901 & 0.014\end{array}$} \\
\hline \multicolumn{7}{|c|}{ Paired Samples Test } \\
\hline & Mea & & St. dev. & $\mathrm{T}$ & df & Sig \\
\hline $\begin{array}{l}\text { TIER2_IAS_39 } \\
\text { TIER2_SNRF_9 }\end{array}$ & 0.95 & & 1.23 & $\begin{array}{l}1.88 \\
7\end{array}$ & 5 & \\
\hline
\end{tabular}

Source: Calculation done by author

The result of variables "TIER2 - IAS 39" and "TIER 2 - IFRS 9" shows that balance of TIER 2 in $2017=17.59 \%$, and the average of TIER 2 in $2018=16.64 \%$, which indicate decries on TIER 2 ratio as a transition to IFRS 9 . The correlation between variables is $\mathrm{R}=0.901$ and interpreted as a strong positive correlation that has a significant impact on the decline of the TIER 2 ratio after the first year of IFRS 9 implementation.

The results of the paired sample t-test showed the level of significance is $11.8 \%$ and $\mathrm{T}=1.887$. The results indicate that we approve the alternative hypothesis (H1) and can conclude that there is no average difference between the TIER 2 ratio before and after implementing IFRS 9 at commercial banks in Kosovo.

\section{Discussion}

The study aimed to answer three setting-specific research question regarding: 
1) The effect of day-one IFRS 9 classification on the balance of assets of Kosovo banks,

2) Its impact on the level of allowance for loan loss, and

3) The total effect in TIER 2 in the first year of implementation of IFRS 9 for commercial banks in Kosovo.

Overall, the day-one effect of IFRS 9 implementation on the balance of assets of the banks in the sample is negative ( $€ 11.6$ million), but relatively small ( $0.36 \%$ of total assets of the banks). The results are in line with the expectations as both early simulations and results after the first post-adoption studies report a negative effect on the balance of assets at the transition date (EBA, 2018) (Supervisory, 2017; Sultanoglu, 2018). Groff \& Morec (2020) conclude that Slovenian banks encounter positive effects as a total, primarily due to country-specific prudential regulation and a series of structural reforms adopted after the financial crises. Similar to our results, her study provides evidence that IFRS 9 effect may not be in line with general prediction under country-specific settings.

Out of six banks in our study, five reported an increase in the allowance for loan loss (Procredit Bank, Raiffaisen Bank, TEB Bank, Banka Kombëtare Tregtare, and Banka Private e Biznesit). Results are in line with literature regarding the increase of provisioning under the new model of impairments. (EBI, 2019; EY, 2018; Deloitte, 2016) The effect of IFRS 9 on the loan loss allowance for banks in a sample is negative ( $€ 10.6$ million) and presents a significant increase in the level of loan allowance ( $0.32 \%$ of the total loan portfolio for banks in the sample). Because of ECL model incorporates historical data and uses the forward-looking concept, the level of allowance for loan losses was increased for five of six banks on the sample because of risk increased (shifting loans from Stage 1 to Stage 2 or 3 based on the risk level).

Transition to IFRS 9 will influence many performance indicators, but the summary effect can be evidenced by capital regulatory. In our study, most of our banks in a sample recorded a negative impact (decries on average for $0.48 \%$ on TIER 2). These results are in the same line with previous literature (EBI, 2019; Blažeková, 2018; A., 2020; Gornjak, 2017), but in case of Kosovo banks decrees on TIER 2 it is statistically significant. According to regulation on bank capital adequacy (2018), the minimum requirement for TIER 2 is $12 \%$ of assets weighted on risk. Based on the data that each bank reported on annual reports, the TIER 2 for banks in the sample on average was $16.48 \%$, and we can say that banks have this indicator in much higher value than the minimum requirements.
The level of significance of the transition to IFRS 9 varies because it depends on the business model, risk-managing strategies, quality of loan portfolio, and composition of assets. Results are on a simple average, but some results for specific banks may have a higher impact on as summary results.

\section{Conclusions}

As opposed to the expected effect of IFRS 9 implementation, only scarce evidence exists on its actual impact. In economic literature, we can find different methodologies used to study effect of IFRS 9 implementation. While Groff and Morec (2020), focused on the aggregate impact of IFRS 9 on banks' equity, EY (2018) study focused on changes in loan loss provisions and coverages ratio. The results of our study differ from the prevailing findings, indicating a day-one impact on assets balance and influence in allowance on loan loss and TIER 2 during the first year of implementation.

Our analysis sheds light on the role of quality of loan portfolio and, consequently, on the transition effect of IFRS 9. We analyze banks in Kosovo, a Western Balkan country, which has inherited a destroyed banking system. Banks in Kosovo have good performance, and the average non-performing ratio is less than 3 $\%$ during the last decade. On transition to IFRS 9, these banks reserved loan loss impairments, which empirically support recent claims by Seitz (2019) that the actual effect of IFRS 9 on impairments strongly depends on asset portfolio quality, especially at the time of favorable macroeconomic outlook.

Although the standard seems to harm financial results, it is difficult to confidently assume that the changes in assets balance, allowances for credit loss, and capital regulatory are a result of the implementation of IFRS 9. We use data from the annual report and financial disclosures, which are not a strong base to conclude that the identified impact is exclusively related to the adoption of IFRS 9 by commercial banks in Kosovo.

Some limitations of this article were identified: the biggest one is related to the fact the data are missing, and financial disclosures do not follow the same standard at all banks in the sample. In this context, we were not able to study the non-performing loan indicator because most of the banks report the impairment after they deduct recoveries. Moreover, some banks in the sample do not have disclosure information about TIER 1, and we investigated the impact of TIER 2.

Also, including in the study only six banks present a relatively small sample, but the differences in asset value create problems in the extraction of accurate and relevant results. Therefore, 
despite the relatively low market shares of these banks, results do not provide a comprehensive effect of IFRS 9 implementation in the Kosovo banking sector.

As a future research direction, the purpose is this study to extend into other countries and to compare results for different states. Also, a more detailed investigation of the ECL model includes here judgment about risk level that presents attractive areas for future research.

\section{References}

1. Barclays. (2017). European Banks" IFRS 9 - Bigger than Basel IV. Barclays. Retrieved from http://www.eifr.eu/document/file/download/1877/bar clays-european-banks-ifrs9-bigger-than-basel-iv-jan17-pdf

2. Basel Committee on Banking Supervisory. (2017). Regulatory treatment of accounting provisionsinterim approach and transitional arrangements. Bank for International Settlements. Retrieved from https://www.bis.org/bcbs/publ/d401.htm

3. Blažeková, P. (2018). The Impact of IFRS 9 (Increase in Credit Risk Provisioning) on Banks' Regulatory Capital. Research Gate. Retrieved from https://www.researchgate.net/publication/322741600 the impact of ifrs 9 increase in credit risk prov isioning_on_banks'_regulatory_capital

4. CBK. (2018). Regulation on Bank Capital Adequacy. Prishtina: Central Bank of Kosovo. Retrieved from https://bqkkos.org/repository/docs/korniza ligjore/shqip/Rregul lorja\%20per\%20adekuatshmerine $\% 20 \mathrm{e} \% 20$ kapitalit $\% 20(002) \cdot \mathrm{pdf}$

5. CBK. (2020). Financial System - Monthly Information. Central Bank of Kosovo, 1-2. Retrieved from https://bqk-kos.org/publications/monthlystatistics-bulletin/?lang=en

6. Charles, T., Shipilovo, A. \& O'Donnell, B. (2017). The Challenges of Implementing IFRS 9Impairment. Global Risk Institute. Retrieved from https://globalriskinstitute.org/publications/challenges -implementing-ifrs-9-impairment/

7. Commission, E. (2016). Proposal for a Regulation of the European Parliament and of the Council Amending Regulation. European Commission No 575/2013. Retrieved from https://eurlex.europa.eu/legalcontent/EN/TXT/?uri=CELEX\%3A52019PC0623

8. Costa, J.F., Lejard, Ch. \& Paget-Blanc, E. (2018). The Implementation of the IFRS 9 in Banking
Industry. HAL archives-ouverts.fr. Retrieved from https://hal.archives-ouvertes.fr/hal-

02405140/document\#: :text=Implemented\%20in\%2 Ofinancial\%20statements \%20from,accounting\%20tre atment \%20with\%20risk\%20management

9. Deloitte. (2014). Fourth Global IFRS Banking Survey - Ready to land. Deloitte. Retrieved from https://www2.deloitte.com/content/dam/Deloitte/ch/

Documents/financial-services/ch-en-financialservices-ifrs-fourth-global-banking-survey.pdf

10. Deloitte. (2016). Six Global IFRS Banking Survey. No time like the present. Deloitte. Retrieved from https://www2.deloitte.com/content/dam/Deloitte/glob al/Documents/Financial-Services/gx-fsi-sixth-ifrsbanking-survey.pdf

11. Deloitte. (2019). After the First Year of IFRS 9. Retrieved from https://www2.deloitte.com/uk/en/pages/financialservices/articles/after-the-first-year-of-ifrs-9.html

12. EAA. (2019). Guide to new Standard IFRS 9, IFRS 15, IFRS 16 and research opportunities. Paphos: IASB. Retrieved from https://www.ifrs.org//media/feature/news/2019/june/basics-of-new-ifrsstandards-and-research-eaa-paphos.pdf

13. EBA. (2018). First Observations on the Impact and Implementation of IFRS p by EU Institutions. European Banking Authority Report. Retrieved from https://eba.europa.eu/sites/default/documents/files/do cuments/10180/2087449/bb4d7ed3-58de-4f66-861e45024201b8e6/Report\%20on\%20IFRS\%209\%20imp act $\% 20$ and $\% 20 \mathrm{implementation.pdf?retry=1}$

14. EBI. (2019). Accounting for Financial Instruments under IFRS 9-First-Time Application Effects on European Banks' Balance Sheets. European Banking Institute Working Paper Series no.48. Retrieved from https://ssrn.com/abstract=3462299

15. ESRB. (2017). Financial stability implications of IFRS 9. European Systematic Risk Board. Retrieved from

https://www.esrb.europa.eu/pub/pdf/reports/2017071

7 fin stab imp IFRS 9.en.pdf

16. EY. (2017). IFRS 9 and the Problem Associated with its Application. Retrieved from https://www.ey.com/Publication/vwLUAssets/EYIFRS-9-And-Its-Impact-On-Regulatory-ReportingFor-Financial-Institutions/\$File/EY-IFRS-9-And-ItsImpact-On-Regulatory-Reporting-For-FinancialInstitutions.pdf

17. EY. (2018). IFRS 9 Impairment Banking Survey. Ernst \& Young. Retrieved from 
https://eyfinancialservicesthoughtgallery.ie/ifrs-9-

impairment-banking-survey-2018

18. Fatohu, M., Bock, R. \& Ouenniche, J. (2020). Impact of IFRS 9 on the cost of funding of banks in Europe. Bank of England working paper No. 851. Retrieved from https://www.bankofengland.co.uk//media/boe/files/working-paper/2020/impact-of-ifrs9-on-the-cost-of-funding-of-banks-ineurope.pdf?la=en\&hash=562C805E2A2412BCD10A 4FD64D3FE851427498F9

19. Frykstrom, N. \& Li, J. (2013, February). IFRS 9 the new accounting standard for credit loss recognition. Risk bank. Retrieved from https://www.riksbank.se/globalassets/media/rapporte r/ekonomiska-kommentarer/engelska/2018/ifrs-9-the-new-accounting-standard-for-credit-lossrecognition.pdf

20. G20. (2009). Declaration on strengthening the financial system. G20. Retrieved from http://www.g20.utoronto.ca/2009/2009ifi.html

21. Gornjak, M. (2017). Comparison of IAS 39 and IFRS 9: The Analysis of Replacement. International Journal of Management, Knowledge and Learning, 115-130. Retrieved from https://www.researchgate.net/publication/319293533 _Comparison_of_IAS 39 and_IFRS 9 The Analys is of Replacement

22. Groff, Z.M. \& Morec, B. (2020). IFRS 9 transition effect on equity in a post bank recovery environment: the case of Slovenia. Economic Research-

Ekonomska Istraživanja. https://doi.org/10.1080/1331677X.2020.1804425

23. Gulyas, E. \& Somogyi, C. (2019). Experiences Relating to the Introduction of IFRS 9 in the Banking Sector. Economy \& Finance. http://doi.org/10.33908/EF.2019.3.3

24. IASB. (2014). International Financial Reporting Standard 9 - financial instruments. IASB. Retrieved from https://www.ifrs.org/issued-standards/list-ofstandards/ifrs-9-financial-instruments/

25. IFRS. (2018). International Financial Reportin Standard 9-Financial Instruments. IFRS Foundation. Retrieved from https://www.ifrs.org/issuedstandards/list-of-standards/ifrs-9-financialinstruments

26. Kosovo, C. B. (2019). Regulation on the Application of the International Financial Reporting Standard 9. Central Bank of Kosovo. Retrieved from https://bqkkos.org/repository/docs/2019/Rregullorja\%20p\%C3 \%ABr\%20aplikimin\%20e\%20SNRF9pril2019.pdf
27. KPMG. (2016). IFRS 9 for banks - What's the impact on your business? KPMG. Retrieved from https://assets.kpmg/content/dam/kpmg/xx/pdf/2016/0 9/IFRS-9-for-banks-flyer-2016.pdf

28. Laurea, D. T. (2018). IFRS 9 - The Interaction Between Accounting and Prudential Frameworks in the Banking System. An Analysis of the First Time Aadoption. Universita Degli Studi Di Padova. Retrieved from http://tesi.cab.unipd.it/62284/

29. Low, E., Schmidt, E.L \& Thiel, F. L. (2019). Accounting for Financial Instruments under IFRS 9 First-Time Application Effects on European Banks' Balance Sheets. EBI Working Paper Series, no. 49. Retrieved from https://ssrn.com/abstract=3462299

30. Novotny-Farkas, Z. (2016). The Interaction of the IFRS 9 Expected Loss Approach with Supervisory Rules and Implications for Financial Stability. Accounting in Europe. Retrieved from https://ssrn.com/abstract=2817983

31. Ntaikou, D. \& Vousinas, G. (2018). Analyzing the expected impact of the newly adopted regulatory regime IFRS 9 on the European banking system's lending channel and profitability. A critical review and future prospects. Retrieved from https://www.researchgate.net/publication/330089076 The expected impact of IFRS 9 on the Greek b anking system's financial performance some theor etical_considerations_and_insights

32. Seitz, B. (2019). From IAS 39 to IFRS 9: Accounting of Financial Instruments in the European Banking Industry. Dissertation of the University of St. Galen. Retrieved from https://books.google.com/books/about/From IAS 39 to IFRS 9 Accounting of Fina.html?id=kmEyxQ $\underline{\text { EACAAJ }}$

33. Sultanoglu, B. (2018). Expected Credit Loss Model by IFRS 9 and its Possible Early Impacts on European and Turkish Banking Sector. 476-506. https://doi.org/10.31460/mbdd.422581 